\title{
有限要素法を用いたリンク機構の逆動力学計算
}

\author{
磯 部 大吾郎*
}

\section{Deriving Inverse Dynamics for Link Mechanisms by Using Finite Element Method}

\author{
Daigoro Isobe*
}

\begin{abstract}
In this study, a scheme using the Finite Element Method (FEM) for calculating inverse dynamics is proposed and applied to open- and closed-loop link mechanisms. In this scheme, the entire system is subdivided into discrete elements and evaluated as a continuum. A single-link structure of a pin joint and a rigid bar is expressed by using the Shifted Integration (SI) technique. The proposed scheme calculates nodal forces by evaluating equations of motion in a matrix form, and thus information from the entire system can be handled in parallel. The obtained nodal forces are then used to calculate the joint torque in the system. Simple numerical tests on open- and closed-loop link mechanisms are carried out, and it is verified that the scheme can be used as a unified numerical scheme independent of the system configuration.
\end{abstract}

Key Words: Finite Element Method, Inverse Dynamics, Link Mechanisms, Nodal Force, Shifted Integration Technique

\section{1. 緒言}

ロボットの歩行動作や複数のマニピュレータによる協調動作 などでは, 系内に開ループと閉ループが交互に発生し, 動力学 方程式（または計算アルゴリズム）を瞬時に入れ替える必要性 が生じる場合がある。しかし，ニュートン・オイラー法やラグ ランジュ法など [1] の従来の手法によるリンク機構の逆動力学 計算では, 閉ループ系が存在する場合としない場合とではその 動力学方程式（または計算アルゴリズム）が大きく異なるため, その実行に大きな困難を伴う，特にロボットの動作が高速化・ 複雑化して力制御の重要性が増すと, 系の変化に対して柔軟に 対応できる統一的な逆動力学計算法の必要性が増すことが考え られる。

本研究では, リンク機構の形態によらない統一的な逆動力学 計算法として, 有限要素法（FEM）を用いた手法を提案する. ニュートン・オイラー法が再㷌的な処理によって動力学方程式 を求める直列的なアプローチを取るのに対し，FEM は，要素 座標系における個々の要素の離散情報を全体座標系の情報に変 換してから重ね合わせる, いわゆる並列的なアプローチを取る (Fig. 1 参照). そのため, 各節点に働く節点力は並列的に求め られ，これを関節トルクに変換することによって逆動力学が計 算される.すなわち, 従来の手法のように関節トルクを求める 方程式を系に合わせて導出するのではなく, 並列的に求めた節

原稿受付 2001 年 10 月 31 日

*筑波大学機能.T学系

* University of Tsukuba
点力情報の中から必要な情報を抽出し, 系に合わせて関節トル クを求めるのである。このような特長を用いると, 対象とするリ ンク系の構成が変化した場合にもアルゴリズムの変更は必要な く, 入力デー夕を変更するのみで柔軟に対処することが可能と なる。しかし本来, FEM は系を細かく離散化 (要素分割) する ことで精度の高い近似解を求める手法であるため, このように 有用な逆動力学計算法となり得る特長を持ち合わせながら, リ アルタイム処理を必要とするリンク機構の動力学問題に対して は適用の範囲外であった. 本研究では, 骨組構造の FEM 解析 でその有効性が立証されている Shifted Integration（SI）法 [2] をリンク機構のモデル化に適用し，この問題を解決した。

リンク機構に FEM を適用した既存の研究としては, フレキ シブル・マニピュレータの先端に生じる振動特性の把握や制御 に FEM を適用した報告例 [3]〜 [5], 大変形角が生じる柔軟体に

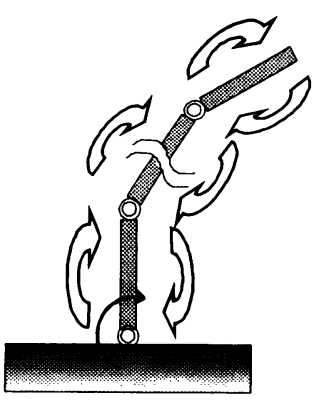

(a) Series approach

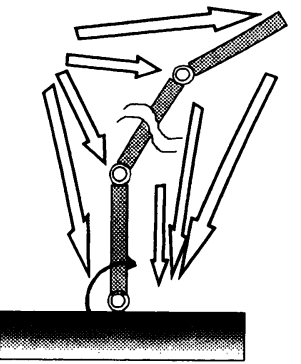

(b) Parallel approach
Fig. 1 Various approaches in deriving inverse dynamics 

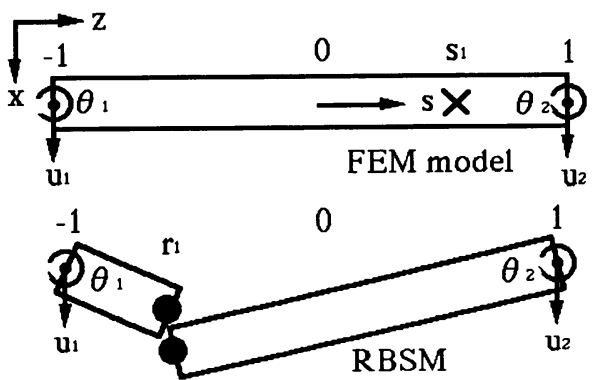

$X$ Numerical integration point

- Rotational and shear spring connecting rigid bars (plastic hinge)

Fig. 2 Linear Timoshenko beam element and its physical equivalent

対する有限要素定式化 [6] および剛体慣性の FEM 解析 [7] など の報告例はあるが，機構全体の逆動力学計算に適用した例は見 当たらない。また，FEM を連続体の制御法として直接適用した 例としては，筆者らが圧電アクチュエータ集合体の制御を FEM によって試みた例 [8]〜[11] がある。この際には，連続体の一部 としてのアクチュエータに必要な電圧が算出され，個々のアク チュエータが独立にではなく，系の一部として制御されること が実験的に確認された。

本論文では, 平面りンク機構に対する FEM を用いた逆動力 学計算法について記述し, 従来の手法の計算結果との比較によ り, 開リンク機構の逆動力学計算における本手法の有効性を論 じる，さらに，節点力を並列的に求解可能である本手法の特長 を利用して閉リンク機構の場合に適用し，脚ごとのトルク配分 比や受動関節位置が変化した場合などについて考察する。

続く第 2 章では, SI 法によるリンク機構のモデル化および陰 解法を用いた逆解析アルゴリズムについて記述する。第 3 章で は, 平面 $n$ リンク機構の場合の FEM による逆動力学計算過程 について述べる．また，第 4 章では開リンク機構に対する計算 を実施し，従来の手法による結果と比較・検討する。第 5 章で は閉リンク機構に対する計算例を示し，本手法の適用範囲につ いて考察する．第 6 章には結論を述べる.

2. SI 法によるリンク機構のモデル化および逆解析アルゴ リズム

\subsection{SI 法によるリンク機構のモデル化}

本研究でリンク機構のモデル化に導入する SI 法は, 本来は骨 組構造の有限要素解析に用いられる手法である. Fig. 2 に示す 線形チモシェンコはり要素と, ヒンジが回転ばねおよびせん断 ばねによって陽に表現される剛体ばねモデル（RBSM）のひず みエネルギー近似式の考察により, 次式のような数值積分点と ばねの位置関係が導出されている $[2]$.

$$
s_{1}=-r_{1} \quad \text { または } r_{1}=-s_{1}
$$

ここに， $s_{1}$ および $r_{1}$ はそれぞれ，数值積分点位置および形成 されるべき塑性ヒンジ（またはばね）の位置である.

SI 法では，上式にしたがってヒンジが生じうる点と対称の位

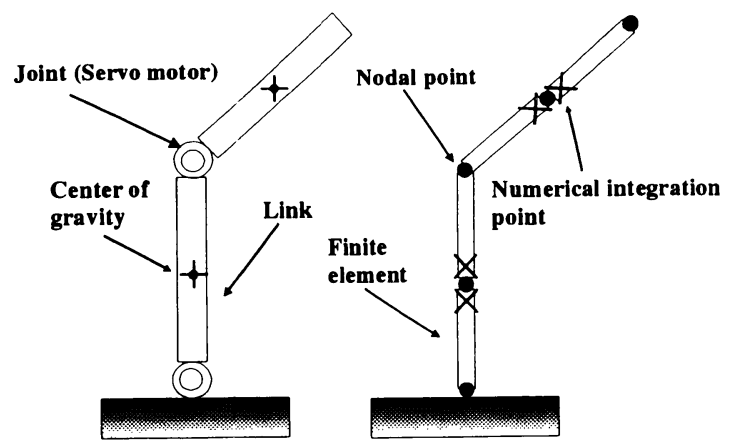

(a) Link mechanism

(b) Finite elements

Fig. 3 Modeling of link mechanism by Shifted Integration technique

置に数值積分点をあらかじめ配置することにより，精度よく骨 組構造物の崩壊荷重解を得ることができる，また，本手法を順 応型に発展させることにより，様々な条件下において最小限の 計算コストで精度の高い解が得られる [12] [16].

剛体ばねモデルのばね剛性を正規化した剛度值を $C_{\mathrm{mot}}$ とおく と,この值を 0 とすればピン, 1 とすれば剛節が表現される. 本 研究では関節をピン状態 $\left(C_{\mathrm{mot}}=0\right)$ と仮定し, 剛体マニピュ レータの逆動力学について従来の手法と比較・検証する. Fig. 3 に，SI 法によるリンク機構のモデル化概念図を示す．図に示す ように，モータとリンク部材によって構成されたリンク機構は, リンクの重心位置に節点を設け, 関節位置の反対側に数值積分 点をシフトした二つの線形チモシェンコはり要素によって表現 される。

\section{2 逆解析アルゴリズム}

本研究では, Newmark の $\beta$ 法 [17]による陰解法を時間積分 法として採用した。また，積分法の中のパラメータを $\gamma=1 / 2$, $\beta=1 / 4$ とし，定加速度法とした。

時刻 $t+\Delta t$ における運動方程式は, 以下のように与えられる.

$$
\begin{gathered}
{[M]\{\ddot{u}\}_{t+\Delta t}+[C]\{\dot{u}\}_{t+\Delta t}+[K]\{\Delta u\}} \\
=\{F\}_{t+\Delta t}-\{R\}_{t} \\
\{u\}_{t+\Delta t}=\{u\}_{t}+\{\Delta u\}
\end{gathered}
$$

ここで, $[M]$ : 全体質量マトリックス， $[C]$ : 全体隇衰マトリッ クス, $[K]$ : 全体剛性マトリックス, $\{F\}$ : 外力ベクトル, $\{R\}$ ： 内力ベクトル, $\{\Delta u\}$ : 変位増分ベクトル, $\{u\}$ : 変位ベクトル, $\{\dot{u}\}$ ：速度ベクトル， $\{\ddot{u}\}$ ：加速度ベクトルである. Newmark の $\beta$ 法では, 時刻 $t+\Delta t$ において加速度べクトル $\{\ddot{u}\}_{t+\Delta t}$ が 求められたとき, 速度べク、トル $\{\dot{u}\}_{t+\Delta t}$ および変位ベクトル $\{u\}_{t+\Delta t}$ を以下のように仮定する。

$$
\begin{aligned}
\{\dot{u}\}_{t+\Delta t}= & \{\dot{u}\}_{t}+\frac{1}{2}\left(\{\ddot{u}\}_{t}+\{\ddot{u}\}_{t+\Delta t}\right) \Delta t \\
\{u\}_{t+\Delta t}= & \{u\}_{t}+\{\dot{u}\}_{t} \Delta t+\left(\left(\frac{1}{2}-\beta\right)\{\ddot{u}\}_{t}\right. \\
& \left.+\beta\{\ddot{u}\}_{t+\Delta t}\right) \Delta t^{2}
\end{aligned}
$$

式（3）と式（4）より, 時刻 $t+\Delta t$ における速度, 加速度べク トルについて, 次の関係が得られる。 


$$
\begin{aligned}
\{\dot{u}\}_{t+\Delta t}= & \frac{1}{2 \beta \Delta t}\{\Delta u\}-\left(\frac{1}{2 \beta}-1\right)\{\dot{u}\}_{t} \\
& -\frac{1-4 \beta}{4 \beta}\{\ddot{u}\}_{t} \Delta t \\
\{\ddot{u}\}_{t+\Delta t}= & \frac{1}{\beta \Delta t^{2}}\{\Delta u\}-\frac{1}{\beta \Delta t}\{\dot{u}\}_{t}-\left(\frac{1}{2 \beta}-1\right)\{\ddot{u}\}_{t}
\end{aligned}
$$

式（5）を式（2）に代入し整理することで，運動方程式は次の ような未知べクトルが一つの連立方程式となる。

$$
\begin{aligned}
([K] & \left.+\frac{1}{2 \beta \Delta t}[C]+\frac{1}{\beta \Delta t^{2}}[M]\right)\{\Delta u\} \\
= & \{F\}_{t+\Delta t}-\{R\}_{t} \\
& +[C]\left(\left(\frac{1}{2 \beta}-1\right)\{\dot{u}\}_{t}-\left(\frac{1}{4 \beta}-1\right)\{\ddot{u}\}_{t} \Delta t\right) \\
& +[M]\left(\frac{1}{\beta \Delta t}\{\dot{u}\}_{t}+\left(\frac{1}{2 \beta}-1\right)\{\ddot{u}\}_{t}\right)
\end{aligned}
$$

さらに, 時刻 $t+\Delta t$ における外力項が時刻 $t$ の外力項と節点力 増分との和で表されることに注意して上式を変形すると, 節点 力増分 $\{\Delta f\}$ は

$$
\begin{aligned}
\{\Delta f\}= & \{R\}_{t}-\{F\}_{t} \\
& +\left([K]+\frac{1}{2 \beta \Delta t}[C]+\frac{1}{\beta \Delta t^{2}}[M]\right)\{\Delta u\} \\
& -[C]\left(\left(\frac{1}{2 \beta}-1\right)\{\dot{u}\}_{t}-\left(\frac{1}{4 \beta}-1\right)\{\ddot{u}\}_{t} \Delta t\right) \\
& -[M]\left(\frac{1}{\beta \Delta t}\{\dot{u}\}_{t}+\left(\frac{1}{2 \beta}-1\right)\{\ddot{u}\}_{t}\right)
\end{aligned}
$$

と与えられる.

一方, 本研究では, 断面力一ひずみマトリックス $[D]$ 内のすべ ての成分に $C_{\text {mot }}$ を掛けることにより, 要素剛性マトリックス $[k]$ を以下のように表した。

$$
[k]=C_{\mathrm{mot}} \int_{V}[B]^{T}[D][B] d V
$$

ここで, $[B]$ は変位一ひずみマトリックスである。また，数值積 分点位置を $s_{1}\left(-1 \leq s_{1} \leq 1\right)$ とし, 要素ごとに以下のような集 中質量マトリックス $[m]$ を定義した，対角項成分のみを示すと，

$$
[m]=\left[m_{1} m_{1} m_{1} \frac{m_{1} l^{2}}{12} \frac{m_{1} l^{2}}{12} t_{1} m_{2} m_{2} m_{2} \frac{m_{2} l^{2}}{12} \frac{m_{2} l^{2}}{12} t_{2}\right]
$$

ここで,

$$
\begin{array}{ll}
m_{1}=\rho A l\left(1-s_{1}\right) / 2, m_{2}=\rho A l\left(1+s_{1}\right) / 2 & (10 \mathrm{a}) \\
t_{1}=\rho I_{z} l\left(1-s_{1}\right) / 2, t_{2}=\rho I_{z} l\left(1+s_{1}\right) / 2 & (10 \mathrm{~b})
\end{array}
$$

である．また， $\rho, A, l, I_{z}$ はそれぞれ，部材密度，部材の断 面積, 要素長, 断面二次極モーメントである. 上記の質量マト リックスでは, 関節が $r_{1}=-1$ (すなわち $s_{1}=1$ ）の位置にあ る場合, $r_{1}=1$ の位置に要素の質量が集中する。一方, 関節が $r_{1}=1$ (すなわち $s_{1}=-1$ ) の位置にある場合には $r_{1}=-1$ の
位置に要素の質量が集中する，すなわち，1リンクを上記の要 素二つで表現することにより，重心位置に質量を集中させた部 材の表現が可能となる (Fig. 3 参照).

本研究では, 剛体リンク系を表現するために $C_{\mathrm{mot}}=0$ とし て $[K]$ を無視した。ささらに, 減衰マトリックス $[C]$ を無視する と式（7）は簡単となり以下のように表される.

$$
\begin{aligned}
& \{\Delta f\}=\{R\}_{t}-\{F\}_{t} \\
& \quad+[M]\left(\frac{1}{\beta \Delta t^{2}}\{\Delta u\}-\frac{1}{\beta \Delta t}\{\dot{u}\}_{t}-\left(\frac{1}{2 \beta}-1\right)\{\ddot{u}\}_{t}\right)
\end{aligned}
$$

本アルゴリズムでは，上式に変位增分および時刻 $t$ における 速度, 加速度を入力することにより節点力増分が算出され, こ れが逐次的に足し合わされて目標の変形を得るために必要な節 点力が求められる. 後述するトルク算出式にこの節点力を代入 することによって，リンク機構の各関節トルクが得られる。な お目標軌道データとしては, 直交座標系に基づく全体空間内の 各関節位置と回転角の時系列を使用する。

\section{FEM による平面 $n$ リンク機構の逆動力学計算}

FEM では連続体の挙動を直交座標系で記述するため，回転 座標系に特有の見掛けの力（コリオリカ）などの非線形項と呼 ばれる力について，独立に考える必要はない。また，いわゆる 重力補償項については，各節点に静的に自重をかけることで対 処する．そのため, 直交座標系における関節トルク算出式は比 較的簡潔となる。

Fig. 4 に $n$ リンク機構内の $i$ 番目のリンクに働く力, および リンク番号と節点番号との間の関係を示す. $i$ 番目のリンクに は，その重心に作用する並進力に起因する回転モーメント, 先 の関節に作用する $i+1 \sim n$ リンクの並進力の合力に起因する回 転モーメント，および重心回りに作用する慣性モーメントが生 じる.したがって $i$ 番目のリンクの関節トルク $\tau_{i}$ は，これらの 和に $i+1$ 番目のリンクの関節トルク $\tau_{i+1}$ を加算したものとな

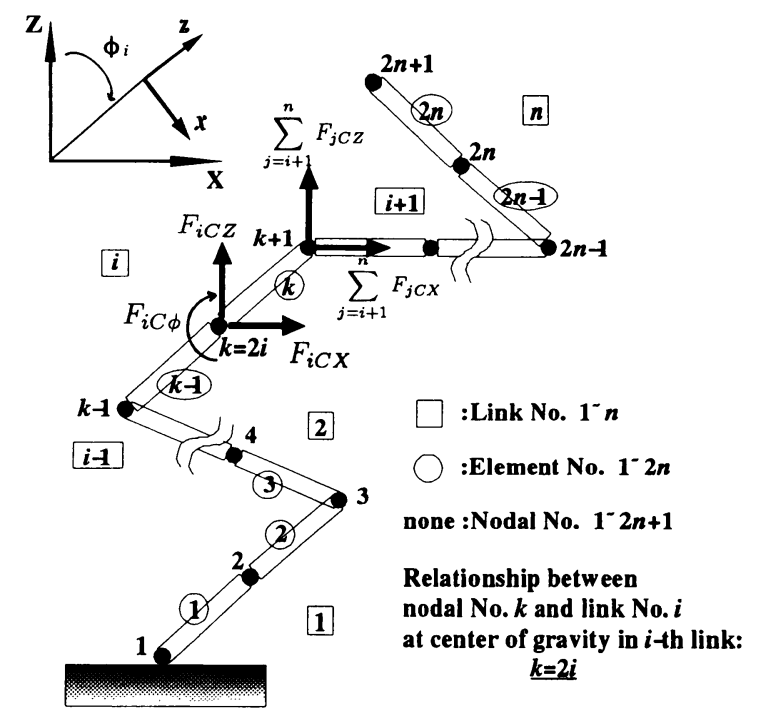

Fig. 4 Nodal force acting on $i$-th link in $n$-link mechanism 
ク,リンク (または要素) 座標系の節点力を用いると

$$
\tau_{i}=l_{i C} F_{i C x}+l_{i}\left(\sum_{j=i+1}^{n} F_{j C}\right)_{x}+F_{i C \phi}+\tau_{i+1}
$$

と与えられる。ここで, $l_{i C}$ は関節から重心位置までの距離, $l_{i}$ はリンクの長さ, $\left(\sum F_{j C}\right)$ は合力を示す. 以後, 変数右下の添字 $i, j$ などは対象とするリンクの番号, $h, k$ は節点番号を示し, $C$ は重心位置での成分, $x, z$ は要素座標系の各軸方向成分, $X, Z$ は全体座標系の各軸方向成分, $\phi$ はY 軸回りの成分であること を示す. また，变数右上の添字 $n$ は対象とする機構の総リンク 数を示す.

式 (12) を $i=1, \ldots, n$ について並べてマトリックス形式に 直し全体座標系で整理すると, 関節トルクベクトルは

$$
\left\{\tau^{n}\right\}=\left[L^{n}\right]\left[T^{n}\right]\left\{P^{n}\right\}
$$

と表現できる. 平面 $n$ リンク機構の場合, $\left\{P^{n}\right\}$ は次のように 定義される $5 n \times 1$ の節点力に関するべクトルである.

$$
\left\{P^{n}\right\}=\left\{\begin{array}{c}
P_{1} \\
P_{2} \\
\cdot \\
\cdot \\
P_{n}
\end{array}\right\}
$$

ただし，

$$
\left\{P_{i}\right\}=\left\{\begin{array}{c}
F_{i C X} \\
F_{i C Z} \\
\sum_{j=i+1}^{n} F_{j C X} \\
\sum_{j=i+1}^{n} F_{j C Z} \\
F_{i C \phi}
\end{array}\right\}
$$

である．また, $\left[T^{n}\right]$ は次のように表される $5 n \times 5 n$ の座標変換 マトリックスである.

$$
\left[T^{n}\right]=\left[\begin{array}{ccccccc}
T_{1} & & & & & 0 & \\
& T_{2} & & & & & \\
& & T_{3} & & & \\
& & & \cdot & & & \\
& & & & \cdot & & \\
& 0 & & & & \cdot & \\
& & & & & T_{n}
\end{array}\right]
$$

ただし, $\left[T_{i}\right]$ は $i$ 番目のリンクの全体座標系からリンク（また は要素) 座標系への座標変換マトリックスで, 座標系間の回転 角を $\phi_{i}$ とおくと

$$
\left[T_{i}\right]=\left[\begin{array}{ccccc}
\cos \phi_{i} & -\sin \phi_{i} & 0 & 0 & 0 \\
\sin \phi_{i} & \cos \phi_{i} & 0 & 0 & 0 \\
0 & 0 & \cos \phi_{i} & -\sin \phi_{i} & 0 \\
0 & 0 & \sin \phi_{i} & \cos \phi_{i} & 0 \\
0 & 0 & 0 & 0 & 1
\end{array}\right]
$$

と表される．従来の方法で関節トルクを算出する場合にはリン ク間の座標変換を繰り返し行う必要があるが, 本手法では平面 リンク機構の場合に全体座標系から要素座標系への変換が一回 行われるのみで済む。このため特にリンク数が多い場合には, 従来の方法に比べてトルク算出の計算時間が大幅に短縮される. 次に, $\left[L^{n}\right]$ は以下のように表される $n \times 5 n$ の部材長マトリッ クスである。

$$
\left[L^{n}\right]=\left[\begin{array}{ccccccc}
L_{1} & L_{2} & L_{3} & \cdot & . & \cdot & L_{n} \\
& L_{2} & L_{3} & \cdot & . & \cdot & L_{n} \\
& & L_{3} & \cdot & \cdot & \cdot & L_{n} \\
& & & \cdot & \cdot & \cdot & \cdot \\
& & & & \cdot & \cdot & \cdot \\
& 0 & & & & \cdot & . \\
& & & & & & L_{n}
\end{array}\right]
$$

ただし，

$$
\left[L_{i}\right]=\left[\begin{array}{lllll}
l_{i C} & 0 & l_{i} & 0 & 1
\end{array}\right]
$$

である．要素座標系に変換された節点力に関するべクトル $\left[T^{n}\right]\left\{P^{n}\right\}$ が上記マトリックスと掛けられることによって, 対 象とするリンクより先の節点力情報が加算される. 部材長マト リックスをさらに次式のように複数の領域に分けることにより, 受動関節の位置, および各能動関節が受け持つトルク配分が操 作可能となる.

$$
\left[L^{n}\right]=\left[\begin{array}{cc}
L^{a} & 0 \\
0 & L^{b}
\end{array}\right]
$$

上式は, 閉リンク機構を $a$ 本と $b$ 本のリンクに分け $(a+b=n)$, その連結部に受動関節がある場合の部材長マトリックスである. 開・閉リンク機構の両者で, アルゴリズムが異なるのはこの点 のみである。

次に, リンク $i$ に生じる節点力増分に関するベクトル $\left\{\Delta p_{k}\right\}$ を以下のように定義する。

$$
\left\{\Delta p_{k}\right\}=\left\{\begin{array}{c}
\Delta f_{k X} \\
\Delta f_{k Z} \\
\sum_{h=k+1}^{2 n+1} \Delta f_{h X} \\
\sum_{h=k+1}^{2 n+1} \Delta f_{h Z} \\
\Delta f_{k \phi}
\end{array}\right\}
$$

このベクトルを用いると, 時刻 $t+\Delta t$ における $i$ 番目のリン クの節点力に関するべクトルは, 以下のように逐次的に求めら れる.

$$
\left\{P_{i}\right\}_{t+\Delta t}=\left\{P_{i}\right\}_{t}+\left\{\Delta p_{k}\right\}, \quad(k=2 i)
$$

節点力増分に関するべクトル $\left\{\Delta p_{k}\right\}$ の各成分はそれぞれ, 節点 $k$ の全体座標系 2 軸方向並進力増分, $k+1 \sim 2 n+1$ 番目の節点 までの全体座標系 2 軸方向並進力増分の和, 節点 $k$ の全体座標 系 $\mathrm{Y}$ 軸回りのモーメント増分となっている. 式 (22)，によって 逐次的に求められたベクトル $\left\{P^{n}\right\}$ を式（13）に代入すること により， $n$ 個の関節トルクの逐次的な值が並列的に計算される. 


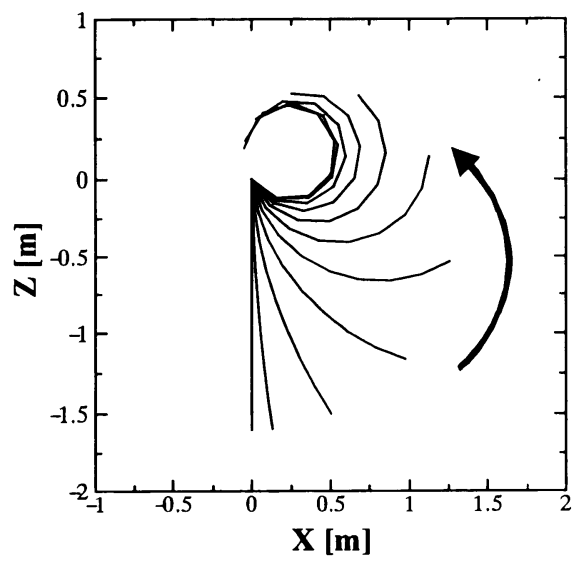

Fig. 5 Target trajectory for 8-link mechanism

\section{4. 開リンク機構の計算例}

本章では, トルク曲線の算出例として $n=8$ の開リンク機構 の場合について取り上げる。ここでは, ニュートン・オイラー 法によって求められたトルク曲線と比較し, 本手法の有効性を 確認する.

Fig. 5 に 8 リンク機構に与えた目標軌道を示す. 長さ $20[\mathrm{~cm}]$ のリンク部材（重心位置：中央, 質量 $107.5[\mathrm{~g}]$ ) を 8 本連結し, 1 秒間（100[step]）で動くように軌道を設定した。また，初期お よび終端速度を $0[\mathrm{~m} / \mathrm{s}]$ とし, 鉛直下向きに重力が作用している と仮定した. Fig. 6 には, 従来のニュートン・オイラー法および FEM を用いた手法によって算出されたトルク曲線を示す。この 数值例では, 全長 $160[\mathrm{~cm}]$ にも及ぶ機構に短時間で急激な動き を与えているため, 重力や遠心力などの影響が大きいことが予想 される. しかしこのような問題でも, 重力を補償しコリオリカを 独立に考慮している従来の手法の結果に対し, FEMによる解が ほほ一致していることが確認できる. 両手法とも Microsoft 社 の Fortran PowerStation 4.0 でコンパイルし, Dell の Dimension XPS T600 (CPU: Intel Pentium III 600 [MHz], RAM: $383[\mathrm{MB}])$ 上で実行した。本手法では，制御対象時間 $1.0[\mathrm{~s}]$ に 対して計算時間はわずかに $0.094[\mathrm{~s}](100[\mathrm{step}])$ に抑えられた。 また,さらにリンク数の多い $n=20$ の場合でも, $0.57[\mathrm{~s}]$ で計 算が終了した。

\section{5. 閉リンク機構の計算例}

Fig. 7 に示すようなはり中央部に質点を載せた簡単な閉リン ク機構に目標軌道を与え, 算出されるトルク曲線を考察して本 アルゴリズムの有効性について検証した。初期および終端速度 は $0[\mathrm{~m} / \mathrm{s}]$ とした.モデルは六つの能動関節を有し, 機構上部 の受動関節に $1[\mathrm{~kg}]$ の質量を配している. 各リンク部材の長さ を $0.5[\mathrm{~m}]$ とし, それぞれの部材の重心位置にも部材の質量を 分配した. 動作時間が 10 秒間の場合 (case 1) と 1 秒間の場合 (case 2) について解析を行い, 算出されたトルク曲線を Fig. 8 に示す. Fig. 8 (a) の case 1 の場合には非線形項の影響が少ない ため, 初期トルクが関節 3 および 6 で質量 $m$ と部材の質量を支 えるのに必要なトルクと一致している。 また，機構が傾くにつ

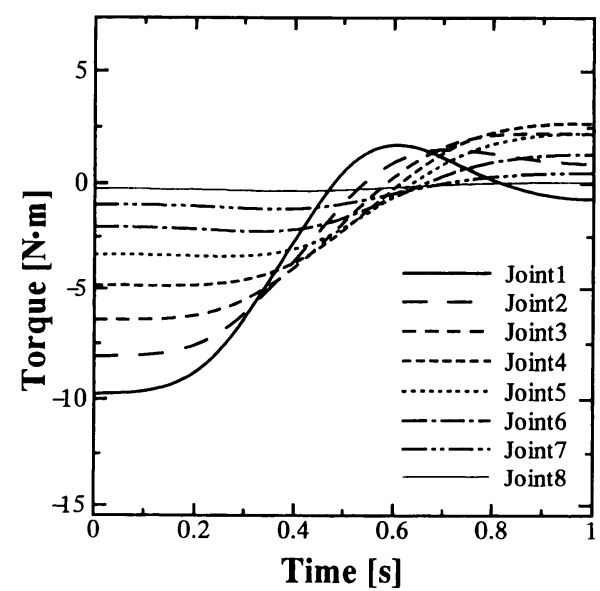

(a) Newton-Euler method

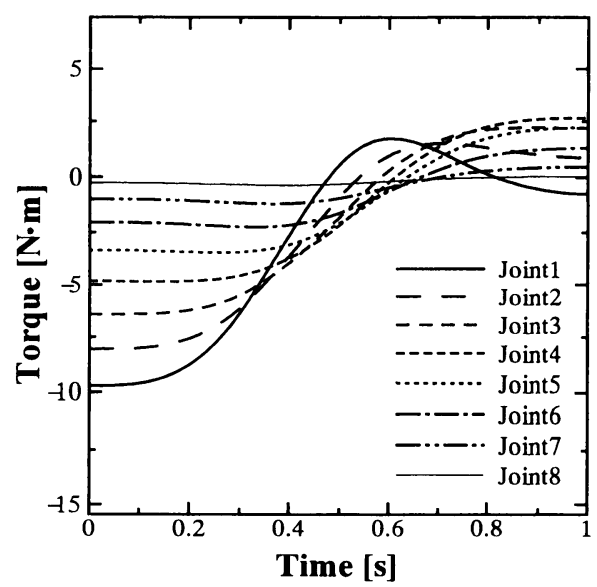

(b) FEM

Fig. 6 Calculated torque curves

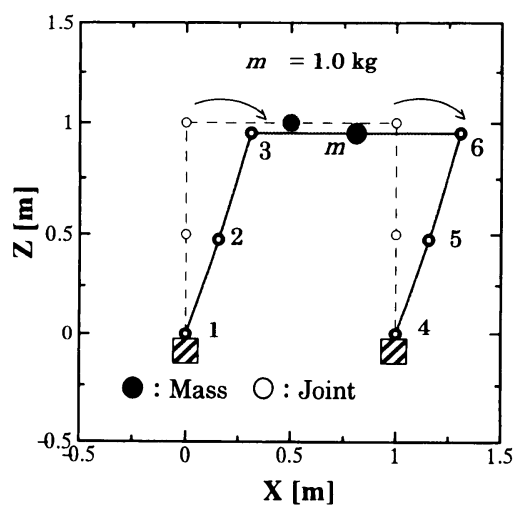

Fig. 7 Target trajectory for closed-loop link mechanism

れてトルク值が負の方向に増大している（トルクは時計回りが 正). 最終的なトルクの值も, 理論的な值と一致した. Fig. 8(b) の case 2 の場合には, 動作時間が短いために初期トルクや曲線 の上下幅などに変動が見られ, 非線形項の影響が考慮された妥 当な結果であることが分かる．

次に, 本モデルの向かって左側と右側の関節のモータが受け 持つトルク配分比を変え, このときのトルク曲線の変化を調べ 


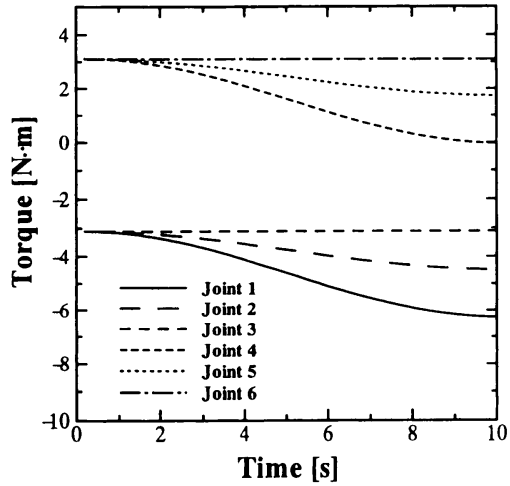

(a) Case 1

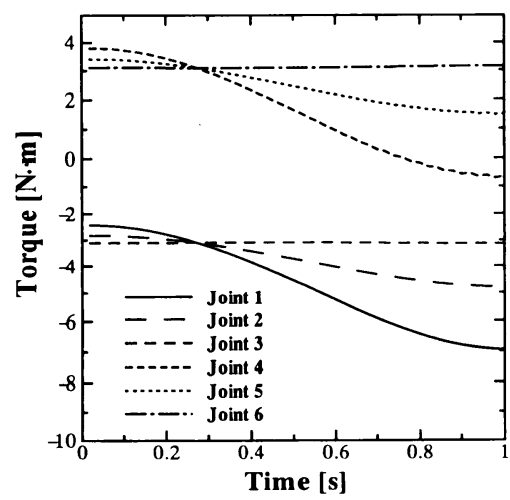

(b) Case 2

Fig. 8 Calculated torque curves

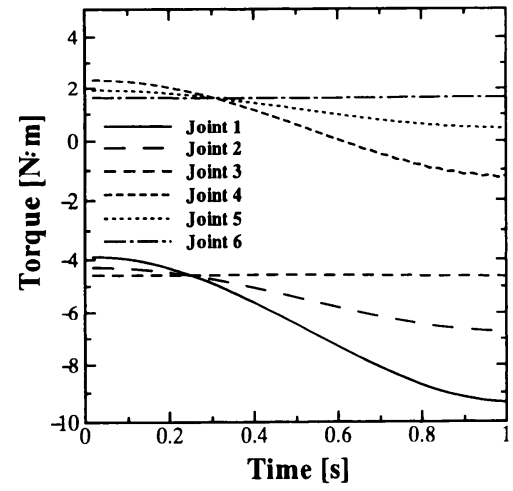

Fig. 9 Calculated torque curves (torque distribution ratio $=$ $4: 1)$

た. Fig.9 に配分比を 4:1にした場合のトルク曲線を示す. 左 側の関節 $1,2,3$ の負担が全体的に増加し，一方，右側の関節 4，5，6の負担が減少していることが確認できる．FEM を用 いた手法では，個々の節点に作用する節点力を独立に求めるた め,このように各関節が受け持つトルク配分比を自由に変化さ せることが可能である。これは，例えば複雑な運動をする歩行 ロボットの機構設計をする際に有用な特長であると考えられる.

さらに，Fig.10のように質点を配した受動関節を右側の節 点に配置した場合の解析を行った。この場合にはトルク配分比 を1：1に戻した．Fig.11にこの場合のトルク曲線を示すが，

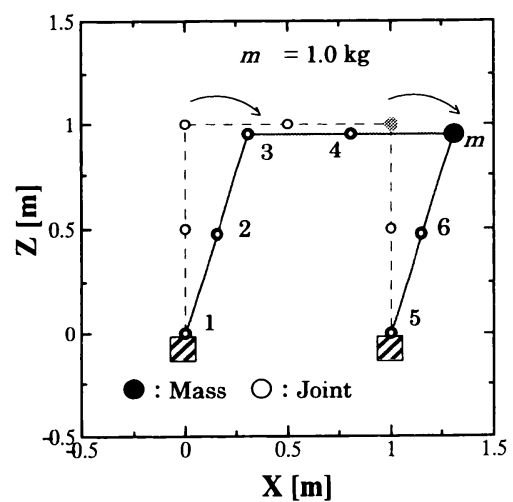

Fig. 10 Target trajectory (passive joint at different point)

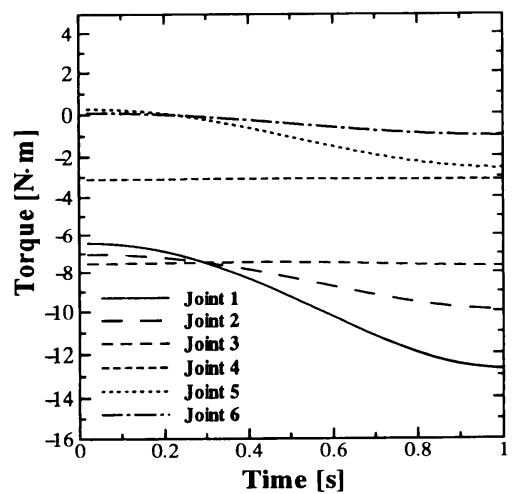

Fig. 11 Calculated torque curves (passive joint at different point)

質点までの距離が長くなった分だけ左側の関節の負担が増大し ていることが分かる，逆に右側の関節は，質点までの距離が短 くなった分だけ負担が減少している，関節 4 では，質点と部材 の重量を支えるためのトルクが算出されている。このように， 受動関節の位置が変化するなど機構に構成変化が生じた場合に も，本手法では入力デー夕を書き換えるのみで対処が可能であ る.また，受動関節での拘束条件を考慮する必要がなく，ソフ トゥェア内の運動方程式などの記述を変える必要がない. 本手 法が有するこの簡便性は，様々な閉リンク機構のパラメー夕設 計をする際に有用であると考えられる。

\section{6. 結}

言

本研究では,リンク機構のモデル化に対して Shifted Integration 法に基づく有限要素を適用し，FEM による逆動力学計算 アルゴリズムを構筑した．形態に応じた動力学方程式を再構築 する必要がある従来の方法に比べ, 並列的に算出した節点力の 情報に基づいて逆動力学を求める本手法は，その算出過程が非 常に簡潔である．また，対象とするリンク系の構成が変化した 場合にも入力デー夕を変更するのみで柔軟に対処することが可 能であり，様々な形態のリンク系が混在，または交互に発生す る場合についても有効であると考えられる. 現在, 三次元リン ク機構への拡張, 部材剛性の考慮によるフレキシブル・マニピュ レータへの適用, 逆動力学によるフィードフォワード制御を組 み込んだ実機の開発などが進められている。 
謝 辞 本研究の遂行に当たり，独立行政法人産業技術総合 研究所の竹内裕喜氏, (株) ボッシュの上田健夫氏 (研究当時大学 院生）には多大なご協力を得ました，また，本研究の一部は文部 科学省 (旧文部省) の科学研究費補助金（課題番号：12750176) の援助の下で実施されました。ここに謝意を表します。

\section{参 考 文 献}

[1] J.J. Craig, 三浦宏文・下山勲 訳：ロボティクス一機構・力学・制 御一. pp.155-188, 共立出版, 1991.

[2] 都井裕：“骨組構造および回転対称シェル構造の有限要素解析に扔け る Shifted Integration 法について”, 日本造船学会論文集, no.168, pp.369-377, 1990.

[3] W.H. Sunada and S. Dubowsky: "On the Dynamic Analysis and Behavior of Industrial Robotic Manipulators with Elastic Members," ASME J. Mechanisms, Transmissions, and Automation in Design, vol.105, pp.42-51, 1983.

[4] E. Bayo: "A Finite-Element Approach to Control the EndPoint Motion of a Single-Link Flexible Robot," J. Robotic Systems, vol.4, no.1, pp.63-75, 1987.

[5] R.J. Theodore and A. Ghosal: "Comparison of the Assumed Modes and Finite Element Models for Flexible Multilink Manipulators," Int. J. Robotic Research, vol.14, no.2, pp.91-111, 1995.

[6] A.A. Shabana: "Constrained Motion of Deformable Bodies," Int. J. Numer. Methods Eng., vol.32, pp.1813-1831, 1991.

[7] A.A. Shabana: "Finite Element Incremental Approach and Exact Rigid Body Inertia," ASME J. Mechanical Design, vol.118, pp.171-178, 1996.

[8] 磯部大吾郎, 中川恒："FEMによる圧電アクチュエータ集合体のリア ルタイム並列制御”, 日本機械学会論文集 (A 編), vol.65, no.629, pp.120-126, 1999.

[9] D. Isobe and H. Nakagawa: "A Parallel Control System for Continuous Architecture Using Finite Element Method," J. Intelligent Material Systems and Structures, vol.9, no.12, pp.1038-1045, 1999.

[10] 磯部大吾郎, 中村博, 清水隆太 : “圧電アクチュエー夕集合体のリア ルタイム FEM 制御システムの開発”，日本機械学会論文集（A 編）, vol.66, no.645, pp.861-866, 2000.

[11] D. Isobe, H. Nakamura and R. Shimizu: "A Real-Time Control System for Connected Piezoelectric Actuators: A FiniteElement Approach," J. Robotics and Mechatronics, vol.12, no.2, pp.172-179, 2000.

[12] Y. Toi and D. Isobe: "Adaptively Shifted Integration Technique for Finite Element Collapse Analysis of Framed Structures," Int. J. Numer. Methods Eng., vol.36, pp.2323-2339, 1993.

[13] Y. Toi and D. Isobe: "Finite Element Analysis of QuasiStatic and Dynamic Collapse Behaviors of Framed Structures by the Adaptively Shifted Integration Technique," Computers and Structures, vol.58, no.5, pp.947-955, 1996.

[14] 磯部大吾郎, 都井裕：“順応型 Shifted Integration 法による脆性骨組 構造体の動的崩壊挙動の有限要素解析”, 日本造船学会論文集, no.180, pp.471-478, 1997.

[15] 磯部大吾郎, 森下真臣：“ASI 有限要素法による大規模宇宙骨組構造 のデブリ衝突解析”, 日本機械学会論文集 (A 編), vol.64, no.627, pp.2726-2733, 1998.

[16] D. Isobe and Y. Toi: "Analysis of Structurally Discontinuous Reinforced Concrete Building Frames Using the ASI Technique," Computers and Structures, vol.76, no.4, pp.471-481, 2000 .

[17] N.M. Newmark: "A Method of Computation for Structural Dynamics," A.S.C.E. J. Engineering Mechanics, vol.85, pp.67-94, 1959.

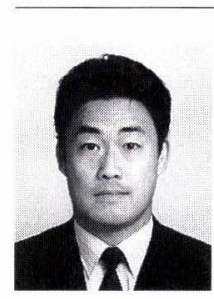

磯部大吾郎 (Daigoro Isobe)

1965 年 7 月 1 日生. 1994 年東京大学大学院工学 系研究科船舶海洋工学専攻修了, 博士 (工学). 同 年東京大学生産技術研究所助手. 1995 年より筑波 大学構造工学系講師. 1999 年より同大学機能工学 系講師, 2002 年より助教授, 現在に至る。構造工 学や計算力学的な手法を積極的にロボット工学に導 入した研究に従事. 日本造船学会, 日本計算工学会, 昍本機械学会, 日本建築学会などの会員.

(日本ロボット学会正会員) 